\title{
A Sketch of Candragomin's Buddhakāya Theory
}

\section{Hidenori S. SAKUMA}

1. Candragomin is generally known as a grammarian or philosopher-poet and dramatist. But since we find a great number of works ascribed to him in the Tibetan Tripițaka and some of his passages quoted by later scholars, he must have been an eminent person in the history of Buddhist thought too. Nevertheless his dates have not yet been determined and, broadly speaking, there are three theories in regard to his dates; namely, he is said to have flourished in the latter half of the fifth century, in the latter half of the seventh century, or at the beginning of the ninth century.

1.1 The first hypothesis concerns Candragomin as the grammarian who wrote the Candravyakarana and other works and is based on a comparison of their content with such works as the Vakkyapadiya by Bhartrhari; this hypothesis was first put forward by Liebich (1899). The second hypothesis concerns Candragomin as the poet and dramatist and is partly based on I-ching's report that Candragomin was alive while I-ching was in India. In addition, Bu-ston's and Tāranātha's histories of Buddhism state that Candragomin was a contemporary of Candrakirti and that a debate took place between them. Frauwallner has warned, however, that one should be careful in using such information.

These two hypotheses have been discussed in detail by Hahn (1974 pp. 1-9) and I have simply followed him here.

1.2 The third hypothesis concerns Candragomin as the logician who wrote the Nyāyasiddyāloka. Steinkellner (1984) compared it with works by Dharmakirti as regards their content and, taking the dates of its translators into consideration, he then concluded that Candragomin would have flourished at the beginning of the ninth century.

1. 3 Recently Mark Tatz has dealt with Candragomin mainly as a Mahā- 
( 24 ) A Sketch of Candragomin's Buddhakāya Theory (H. SAKUMA)

yānist or Yogācārin and has placed him in the latter half of the seventh century. Tatz (1982, pp, 4-7) has classified the works of Candragomin from the viewpoint of their subject matter, listing them under the following headings: Didactic. Commentary, Grammar, Drama (Kāvya), Praise (Kävya), Tantric practice and References to Lost Works. I do not have any intention of dealing here with the question of whether or not all these works should be ascribed to the same author.

2 Under the heading "References to Lost Works" Tatz gives three lost works by Candragomin, one of them entitled the *Trikāyāvatāra according to Bu-ston's and Tāranātha's histories of Buddhism ${ }^{1)}$. This work is neither included in the Tibetan Tripitaka nor can it be identified with the text of the same title (P. ed. No.5290; D. ed. No, 3890). On the other hand we find passages ascribed to Candragomin which are quoted in dealing some later texts, mainly in commentaries of the Abhisamayālamkāra and dealing with the Buddhakāya theory in the Yogācāra system. This paper attempts to analyze these passages and probes the possibility of identifying the *Trikāyāvatāra with these passages.

3 The quoted passages may be divided into two types in accordance with their content: the one is from the Munimatālamnkāra by Abhayākaragupta and the Samskrtāsamskrtaviniścaya by Daśabalaśrimitra (Skilling 1990) and the other from Tson-kha-pa's and hJam-dbyans-bshad-pa's commentaries on the Abhisamayālamkāra.

3.1.1 The first type of the quoted passages appears as follows:

Abhayākaragupta, Munimatālaṃkāra P. No. 5299 Ha 287b8ff.; D. No.3903 A 219b1ff.

slob dpon tsandra go mis kyan gsuñs pa/

1 de bshin ñid ni chos skuho ḥdi//rnam rtog rnams kyi spyod yul min// sems can dan don kun gyi//ran bshin de ni gñis med paḥo//

2 sna tshogs gzugs can sku rnams dan்// hgro rnams de bshin ñid no bor// gań du ro gcig gyur pa na// rgyam tsho ru ni chu bo bshin//

3 ḥdi ste rnam pa ḥdi ltahi sku// skyob pa hadi yi chos skuho// rnam pa thams cad rnam dag phyir// rdzogs paḥi byan chub kho naḥi yul// 


\section{A Sketch of Candragomin's Buddhakāya Theory (H. SAKUMA)}

4 hijig rten rnams su lhun grub par// rtag tu de yi nus pa rnams// ñi maḥi họn zer rnams bshin du// mthah yas pa yi don rnams $\mathrm{mdzad} / /$

5 dmus lon lta bu bdag gshag pa// rañ gi bsod nams kyi bskyed pahi// mig cag kun gyi gcig pu ste// cig car ñi ma bshin du mthon //

6 dehi chos bdud rtsihi bcud kyis len// hon pa lta bu bdag bshag pahi// skal ba ldan rnams bsod nams kyis// bskyed pahi rnabs da ltahan ñan//

7 skad cig skad cig theg gsum gyis//sa bon ji ltar bsam ji ltar// mthah med phyogs su mthah yas pahi// sems can hdi yis sbyon bar mdzad// ces so//

Dasabalasrlmitra, Saṃskrtāsamskrtaviniścaya, P. No. 5865 Ño 237a3ff.;

D.No. 3897.

dge bsñen chen po zla baḥi shal nas/ chos kyi skuhi dbañ du byas na gsuñs pa/

1 ḥdi yi chos sku de bshin ñid// rnam rtog rnams kyi spyod yul min// sems can rnams dan don rnams kyi// ran bshin de dag gñis su med//

2 sna tshogs no bohi sku rnams dan்// hgro rnams de ñid no bo rnams// gań du ro gcig ḥgro hgyur ba// rgya mtshor habab pahi chu bo bshin//

3 rnam pa ḥdi ḥdrahi sku de ni// skyob pa rnams kyi chos sku ste// rnam pa thams cad rnam dag pa// rdzogs byan chub kyi spyod yul ñid//

4 de yi nus pa ran் ṅan gis// dus rnams kun tu hjig rten du// mthah yas don rnams byed pa ni// ñi maḥi ḥod zer lta buho//

lons spyod rdzogs pahi dban du byas pa ni//

5 dmus lon lta bus bdag spańs nas// ran ñid bsod nams bsags can gyis// de ni gcig pu gcig car du// ñi ma lta bur kun gyis mthon //

6 hon pa lta bu bdag spañs nas// bsod nams nor bsags sñan rnams kyis// dam chos bdud rtsihi bcud len ni// de la de rin yañ ldan pa ñid//

ces so// sprul pahi skuhi du byas pa ni/

7 mthah yas phyogs su mthah med pahi// sems can theg pa gsum gyis hir// yan் dag yań du rnam dag byed//sa bon ci bshin bsam ji bshin// shes so//

If one disregards differences in terminology, it should be evident that these two quoted passages, namely from Nos. 1 to 7, are identical. As regards their content, they present a threefold buddhakāya system that clearly belongs to the traditions of the Yogācāra school. It is worth noting that this passage was known not only in the Abhisamayālamkāara tradition 
( 26 ) A Skketch of Candragomin's Buddhakāya Theory (H. SAKUMA) but also in other traditions.

1 His dharmakaya is the ultimate reality (tathata), which is beyond the sphere of discrimination (avikalpagocara), and is not separate (advaya) from the true nature of sentient beings (sattva) and phenomenal things.

2 The various forms of bodies (viśvarūpa) and the [sentient and nonsentient] existents are characterized by the ultimate reality, which is everywhere in complete harmony (ekarasa) just like water merging into the ocean.

3 This form of body is the dharmakaya of the Protectors, which is the sphere of only perfect enlightment (sambodhi) because it is perfectly pure in every aspect.

Because of lack of space I shall refrain from translating the remaining verses.

3.1.2 The Buddhakāya system of this passage is, roughly speaking, such that the dharmakāya characterized by both tathat $\bar{a}$ and $j \tilde{n} \bar{a} n a$ is a generic term and transforms into either the sämbhogikakāya or nairmānikakāya for the sake of benefitting of the sentient beings. This system is in clear agreement with the thought of the Mahāyānasūtrālamkāara-kāaikīāIX-60ff. and should be located in Yogācāra buddhakāya tradition (Sakuma 1987, 1989).

3.2.1 The second type quotation is that quoted by Tson-kha-pa and h.Jam-dbyañs bshad-pa.

Tson-kha-pa, gSer phren, Tsha 247a6ff.

tsa ndra gau mis/

8 gañ yan kun gshi rnam par śes// me lon ye śes ñid gyur pa// de yan chos kyi dbyins kyi ni// no bo ñid du hgah shig hdod//

9 ñon moñs can yid gnas gyur pa// mñam ñid ye śes brjod par bya// so sor rtog pahi ye śes ni// yid kyi rnam śes ñid deho//

de dag lons spyod rdzogs sku ñid//

ces dañ/

10 kha cig me lon ye śes kyañ// lońs spyod rdzogs pahi sku ru rtogs// de yań de la rgyu ñid phyir// ñe bar btags pas de bshin gshan// 
A Sketch of Candragomin's Buddhakāya Theory (H. SAKUMA) ( 27 )

11 dbań po lna yi rnam śes gañ// de ni don kun yońs hadzin phyir// sems can kun gyi don $\mathrm{du} \mathrm{ni} / /$ bya ba sgrub pa tsam ñid thob//

12 de yan் rtag par thams cad du// dus ji bshin dañ bsam ji bshin// sańs rgyas rnams kyi sprul sku ste// sprul ba kun gyi rgyu yin phyir//

13 kha cig yid kyi kho na la// sprul pahi sku ñid du ni rtag// dbań po lna yi rnam śes gan்// de yi lońs spyod rdzogs skur ro// shes dgońs rgyan du dran்s so//

hִJam-dbyans-bshad-pa. sKabs brgyad pahi mthah dpyod hadhrul sel Ganggāhi

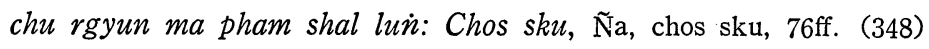
tsa nda go mis kyañ/

8 gań yan் kun gshi rnam par śes//me lon ye śes ñid gyur pa// de gan chos kyi dbyińs kyi ni// no bo ñid du ḥgạ shig ḥdod//

9 ñon monis can yid gnas gyur pa// mñam ñid ye śes brjod par bya// so sor rtogs pahi ye śes ni// yid kyi rnam śes ñid deho//

de dag lons spyod rdzogs sku ñid//

ces gsuńs pahi phyir...

tsa ndra go mis/

12d dehi rjes de ma thag pa/ sprul ba kun gyi rgyu yin phyir// shes gsuns pahi phyir/ tsa ndra go mis/

13cd dbañ po lna yi rnam śes gan்//de ni lons spyod rdzogs skur ro// shes gsuñs pahi phyir/...

tsa ndra go mis/

14 chos la rdzogs lon spyod sñon ni//byan chub sems dpaḥ chen po rnams// chos la rdzogs loins spyod phyir yain// shes gsunis pahi phyir...

3.2.2 When comparing these two quoted passages, it is found that Nos.8, 9, $12 \mathrm{~d}$ and $13 \mathrm{~cd}$ are identical, It is possible that hJam-dbyan-bshad-pa quoted them simply from the gSer phren, but to the best of my knowledge No. 14 does not appear in the $g$ Ser phren. This means that the original text of this quotation have existed and that No. 14 derived from this text.

I shall select and translate only the important verses in order to examine the buddhakāya system to which they give expression.

8 It is said that the alayavijñana is transformed into the a darsajñana 
( 28 ) A Sketch of Candragomin's Buddhakāya Theory (H. SAKumA) whose original nature is the dharmadhätu.

9 It is said that the kliștamanas is transformed into the samatāiñ $\bar{a} n a$ [and that] the manovijñanna [is transformed into] the pratyavekșajñāna.

10abc Some understand that the ãdar'sijñana also appertains to the sammbhogikakāya, because it is its origin. (MSAbh: the sambhogikakaya is the origin of the sambhogabuddha. Sakuma 1987)

11 In order to benefit all sentient being, only the vijñana of the five organs obtains the krtyānușthāna[-jñāna], because it grasps all objects well.

12 As it appears of any time, anywhere, as the occasion demands and at will, it is at the same time (yan) the nairmanikakāya of the Buddhas, because it is the origin of all manifestations.

13 Some understand that only the mano [-vijñana] appertains to the nairmanikakāya. The vijñana of the fiive organs appertains to the sāmbhohogikakāya.

Tson-kha-pa then adds "In this way [the passage] is quoted in the Munimatālamkāära"

3.2.3 Here we find three different theories on the buddhakāya system, and it is to be assumed that Candragomin wrote this passage after these theories had been already established after much discussion about them. In fact Nos. 9 and 11, in which the combinations "manovijñanna: pratyavekșājñāna" and "pañcendriyavijñāna: krtyānșthānajñāna" have already been fixed, would have been written at the time of or after, for example, Sthiramati (Sakuma 1987, 1984). No. 10 seems to suggest the theory of, for example, Hsüan-tsang in the Fo-ti-ching-lun 仏地経論 and the Ch' engwei-shih-lun 成唯識論 (Sakuma 1987, 1989). In this case Candragomin would have been active in the latter half of the seventh century.

4 As mentioned above, according to Tson-kha-pa this passage by Candragomin was quoted from the Munimatālamkāra. I have not, however, been able to find any identical passage in the Munimatālamkāra but only a passage corresponding to Nos. 1 to 7 . This is somewhat strange, but as 
A Sketch of Candragomin's Buddhakāya Theory (H. SAKUMA) ( 29 )

regards content we may interpret this fact as follows: Nos. 1 to 7 correspond to the presentation of this system (=MSA-k, MSAbh, etc.) while Nos. 8 to 14 indicate more developed theories such as those of SAVbh by Sthiramati or the Ch'eng-wei-shih-lun 成唯識論 translated and compiled by Hsüan-tsang. There are no contradictions between the first and second type of quotation, and so it may be assumed that both derive from the same work by Candragomin and that this work was the lost *Trikāyāvatāra by Candragomin.

Hahn, Michael

1974 Candragomins Lokanandanataka, Nach dem tibetischen Tanjur herausgegeben und übersetzt, Ein Beitrag zur klassischen indischen Schauspieldichtung, Otto Harrassowitz, Wiesbaden.

Liebich, Bruno

1899 Das Datum des Candragomin." In: Wiener Zeitschrift für die Kunde des Morgenlandes, Bd. 13, pp. 308-315.

Tatz, Mark

1982 The Life of Candragomin from Tibetan Sources." In: Tibet Journal vol. 7, No. 3, pp. 3-22.

Skilling, Peter

1990 A Possible Citation of Candragomin's Lost "Kāyatrayāvatāra". In: The Journal of the International Association of Buddhist Studies. vol. 13, N. o1, pp. 41-51.

Steinkellner, Ernst

1984 "Miszellen zur Erkenntnistheoretisch-Logischen Schule des Buddhismus". In:

Wiener Zeitschrift für Kunde Südasiens, Bd. 28, pp. 177 178.

Sakuma, Hidenori-Shūhan

1983 “四智と八識との結合関係—その成立過程—” IBK 32-1, pp. 124-125.

1984 “〈智〉と〈識〉一両者の結合関係とその成立過程—” Buzan Gakuho 28/29, Tokyo, pp. 125-141.

1987 “〈三身〉と〈五法〉一一両者の 結合関係とその成立過程—”高崎直道博士還暦記 念論集「インド学仏教学論集」(Festschrift for Prof. Dr. J. Takasaki on His 60th Birthday), Tokyo, pp. 387-411.

1989 “玄曻に护ける〈仏身〉の扱い方” Bukkyobunka, 22 (25), Tokyo, pp. 94-108.

1) Bu-ston: (Tib. Text ed. L. Chandra, p. 836, 1. ; English Tr. by Obermiller, Part II.p. 133. ) Tāranātha: (Tib. Text ed. A. Schiefner, p. 120, 17; Japanese Tr. by Teramoto, p. 226)

〈Key Words〉 Candragomin, Buddhakāya, Yogācārin

(Associate Professor, Shitennōji International Buddhist University, Ph.D.) 